\title{
The Importance of Using High Quality Seeds in Agriculture Systems
}

\author{
Sabry G Elias* \\ Oregon State University, USA \\ Submission: March 15,2018; Published: April 25, 2018 \\ *Corresponding author: Sabry G Elias, Oregon State University, USA, Email: Sabry.Elias@oregonstate.edu
}

\section{Opinion}

The use of high quality seeds is one of the most important elements in increasing agricultural production in any farming system. This element has become more crucial than ever for providing enough food security for the rising number of people in the world, which is expected to exceed nine billions by year 2050. Selecting high yielding varieties adapted to the area of production, with disease, insect, lodging, and shattering resistance, along with other desirable characteristics are basic keys for satisfactory crop performance and yield. The production of high quality seed is the cornerstone of any successful agriculture program. It is also a good marketing tool for increasing the potential sale of crops, especially in today's competitive market.

Many people wonder what does seed quality mean? The practical definition of seed quality can differ depending on the end user. For example, a farmer may desire high-quality seed that produces rapid uniform plants with high yielding capacity under a wide range of field conditions. A producer of oil seed crop, where oil would be used for industrial purposes such as making soap, cosmetic products or lubricants may desire seed with a particular stable fatty acid profile as a measure of high quality.

In general, the quality of seeds is measured in many ways, including genetic and physical purity, germination, vigor, uniformity in sizes, freedom from seed-borne diseases, and any other factors that may affect seed performance in the field. Examples of the factors that affect seed quality are heat, mechanical damage, and pre-harvest sprouting in white wheat. Therefore, seed quality is a collective term for the conditions of seeds including genetic and physical purity, viability, vigor and seed health. Other characteristics such as specific chemical composition or resistance to certain diseases or insects also contribute to the quality of seeds.

Many factors influence seed quality. Complex interactions of genetic, environmental, physiological, biochemical, cytological, and pathological factors influence the expression of seed quality. Factors under genetic control may include, but not limited to, seed size, and color, chemical composition, hard-seededness, hybrid vigor, susceptibility to mechanical damage, and disease resistance.

Success in producing quality seed of a particular crop in one area and failure in another area illustrates the importance of environmental influence on seed development and maturation.

Environmental conditions during seed development and maturation, including temperature, water stress or excessive rain, lack of nutrients, disease infestation, and insect pressure influence seed quality. The stage of seed development at harvest also affects seed quality. Harvesting too early or too late may reduce the quality of the seeds. During prolonged and less than optimum storage conditions, physiological, biochemical, and cytological changes occur in seeds, leading to the deterioration of their quality. Slower growth rate, abnormal seedlings, and loss of vigor and viability are among the physiological changes. Mechanical injuries due to harvesting, conditioning, and handling can also affect seed quality.

Storing seed under poor conditions of high temperature and relative humidity or at high moisture content accelerates seed deterioration and reduces its quality. The extent of seed deterioration depends on species, storage environment, length of storage period, and the initial quality of the stored seeds. Therefore, testing the quality of seeds stored for different lengths of time is important to determine the effect of aging on seed quality.

In summary, the production of high quality seeds does not happen by chance. Each step in the production system from planting the proper variety in appropriate time to following weed control practice, fertility program, harvest in the right time, cleaning the seeds, storage, and shipping is critical for achieving high quality seeds. 
This work is licensed under Creative Commons Attribution 4.0 License

DOI: 10.19080/ARTOAJ.2018.15.555961
Your next submission with Juniper Publishers will reach you the below assets

- Quality Editorial service

- Swift Peer Review

- Reprints availability

- E-prints Service

- Manuscript Podcast for convenient understanding

- Global attainment for your research

- Manuscript accessibility in different formats

( Pdf, E-pub, Full Text, Audio)

- Unceasing customer service

Track the below URL for one-step submission https://juniperpublishers.com/online-submission.php 